\title{
An Investigation on the Anxiety of Turkish Mothers Living in the USA about Their Children's Future
}

\author{
Sengul Ilgar*, Nihat Topac \\ Department of Primary Education,Istanbul University, Hasan Ali Yucel Faculty of Education, Istanbul,Turkey \\ *Corresponding author: sengulilgar@hotmail.com
}

Received July 31, 2014; Revised August 15, 2014; Accepted August 21, 2014

\begin{abstract}
The purpose of this study is to investigate the anxiety of Turkish mothers from different socio-economic levels about their adolescence period children's future. The investigation is a qualitative study composed of 24 mothers. In the analysis of interview results, descriptive analysis method was used in line with qualitative data analysis. When the anxiety of mothers in different socio-economic level families about their children's future was investigated, all mothers in higher, middle and lower socio-economic levels had the anxiety that their children would alienate from Turkish culture, feel shy about being Turkish, have a cultural dilemma and find our cultural values nonsense. While the children's being unwilling to learn Turkish and forgetting the language was the first anxiety that middle class family mothers mentioned, higher socio-economic level mothers stated their anxiety about their children's getting married to a non-Turkish person.
\end{abstract}

Keywords: adolescence period, anxiety, mothers, Mothers In The USA

Cite This Article: Sengul Ilgar, and Nihat Topac, "An Investigation on the Anxiety of Turkish Mothers Living in the USA about Their Children's Future.” American Journal of Educational Research, vol. 2, no. 9 (2014): 745-751. doi: 10.12691/education-2-9-7.

\section{Introduction}

In the studies about the Turkish people living abroad, it is observed that they go through a variety of problems because of different reasons. These problems could bring about a plenty of anxieties.

It is of great importance to provide education upon mother tongue, culture and history for our children and the youth living in foreign cultures. It is both required to protect their culture, individuality and help them adapt the culture they live. Living in different cultures might lead to different anxieties.

Our citizens come from a different culture and they struggle to maintain their relationship with their culture. It is contingent to say that one of the most vital anxieties the parents have is that they are unable to raise their children as they wish. Their children are also moving further from the cultural values and behaviors that the parents own [1].

The people who decide to live in a foreign country cannot continue to live without learning the language and the culture of the country they live in. Otherwise, this is problematic and unacceptable for both themselves and the country they are living in. It is also problematic and unacceptable to force them to abandon their languages and countries completely [1].

One of the dilemmas for the children of Turkish parents in Germany is the concern for their children's likelihood of a breakaway from their own culture. There are, without doubt, Turkish children that forced better education opportunities after they were born, had pre-school education and had good relationships with their German friends. However, the children in that condition drifted quite away from Turkish culture [2].

For the Turkish people in Europe, there should be more importance upon constructing the educational environment to improve the mother tongue levels up to sufficient levels. As a matter of fact, it is expected from a bilingual individual to use both his mother tongue and his second language fluently. In addition, this individual has to display an attitude that is open to communication, integrated in the society he is living in. This individual is supposed to behave appropriate for both nations' customs and traditions [3].

Second generation Turkish children in the United States of America, preferred English to a higher degree as they got older, which was directly proportional to their spending less time with their family. As a result of this, it is observed that these children felt themselves closer to the foreign culture in the process of time [4].

The immigrants living in the United States of America had difficulties in protecting their mother tongue and their culture. Generally, the families wished their children to learn English in advanced levels and adapt themselves to American culture. On the other hand, these children were also expected to protect their mother tongue and cultures [5].

Upon the interviews with Turkish family members, there was a finding. It suggested that when Turkish was preferred more at home, people worried that the children's academic success at school would be less. However, the studies showed that these concerns were baseless. For instance, in a research upon the high school students in the 
United States of America, there was not a decline in the academic success of students who were fluent in English and their mother tongue. On the contrary; a positive effect was observed within these students. In another research, no connection was found between English reading skills and knowing two languages [4].

When the expressions of feelings by the parents were researched; differences appeared in the expression of feelings from mothers' and fathers' sides. Especially, mothers were observed to be expressing their feelings more than the fathers did. This underlined the possible differences of raising children and expressing the feelings [6].

Anxiety is seen with regards to different behaviors such as psychological and psychomatic indications. The general concern is, in fact, it is accepted as a concept based on fear, stress states [7].

According to Spielberger and colleagues (1970) anxiety is divided into two parts as the state of anxiety and continuous anxiety. State Anxiety is defined as a subjective fear the individual fears because of his situation, and continuous (trait) anxiety is the individual's inclinations to state of anxiety [8]. According to Özer (2001) [9], anxiety is not created by the events itself, but by the interpretation ways of events. According to Köknel (2013) [10], fear can be accepted as anxiety’s leading to a situation, a person, an object, a phenomenon and focusing, collecting, intensifying on them.

The studies regarding the problems, concerns and expectations of Turkish people living abroad were quite few in recent years. When it is considered that scientific researches are necessary to help Turkish people there, our study carries importance in a response -though partly- to that need and it draws attention to the case. Within that context, this study will form a base for the academicians, public institutions and civil society organizations to conduct scientific research upon Turkish people living abroad. It will also aid to carry out some practices effectively.

\section{Method}

\subsection{The Method of the Research}

This research is a qualitative study regarding the mothers with children of adolescence period and their anxieties about the children's future. Qualitative study is defined as a research type that follows a qualitative process in order to present perceptions and events in natural environments in a realistic and integrated way. This method uses qualitative data collection methods such as interviews and document analyses [11].

\subsection{Study Group}

This study was conducted with the data collected from 24 Turkish mothers living in the USA. They were determined by purposive sampling method.

The sample of the study was consisted of 6 Turkish mothers from lower socio-economic level, 9 Turkish mothers from middle socio-economic level and 9 Turkish mothers from higher socio-economic levels. All the mothers were with children of adolescence period and they lived in Philadelphia. In this study only mothers were included in the research. The reason for that was mothers were primarily responsible for the care and the education of the child and their relationships with their children were friendlier. The income levels of the families were detected after asking the mothers for this information. When the ages of the mothers were analyzed, 3 of them were between 25 -30 years old; 16 of them were between 30-35 years old, finally 5 of them were between 35-40 years old. The education levels of the mothers were also stated. 15 mothers had college degrees and 9 mothers were highschool graduates. All the mothers participated in this research were Muslim. These mothers had been living in the USA for at least more than 8 years and they were first generation immigrants.

The mothers included in the study were selected according to the principle of voluntariness. The researcher got permission from the mothers after explaining the study. The researcher interviewed with the mothers in this area because the number of the Turkish families living in Philadelphia was high. 52 mothers were contacted, 21 mothers were not included in the study, as they did not have children in the adolescence age. In addition, 7 mothers rejected to participate in the research. Therefore, this study was conducted within a limited number of mothers (24 mothers).

The mothers in the study group were given code names and their expressions were quoted.

\subsection{The Means of Data Collecting and Collection of Data}

The data was collected mainly through a halfconstructed interview form. The interview consisted of one open-ended question. The question was "What are your concerns for your children's future?” And it was prepared by the researchers.

Interview is the most frequently used method in qualitative research methods. The basic method used in interview is oral communication. Qualitative researchers who use the interviews must be educated about the features, preparation and conducting processes of this method. There is a very important convenience for the half-constructed interview. The interview is conducted according to the pre-arranged interview protocol and, thus it presents more systematic and comparable information [11].

The interviews were conducted in order to collect data by one of the authors (Sengul Ilgar) who had been studying as a researcher for a year in the USA.

The interviews were conducted with Turkish mothers living in the USA with children of adolescence period. The mothers in the USA were contacted after the suggestions of some families (families suggested the other families) living in Philadelphia. During this contact period, the mothers were selected according to their different levels of socio-economic features. The interviews were carried face to face and one-to one. The mothers were asked to tell their concerns about the children's future. Later, 3 people being experts in their study areas read the answers and classified them into categories. The irrelevant answers were left out.

After the assay, the data was analyzed via descriptive analysis. 


\section{The Analysis of Data}

Descriptive analysis method is used while the data is analyzed. The objective is descriptive analysis shapes the raw data for the readers to understand and use the data when they need. Descriptive analysis is summarized and interpreted according to the prearranged themes. In this type of analysis, direct quotes are frequently included to present the views of the observed individual in a striking way [11,12]. Qualitative researches provide validity by being inclined to the research area, face to face interviews and gathering deep data. These studies also provide validity by collecting data via observation, re-studying the area to confirm the data. They also have the potential to collect additional data [11]. In this study, the data was evaluated after collecting data directly from the participants.
In the study, mothers with children of adolescence period gave different responses when they were asked to express their concerns for the future of their children. The answers were read after that. First of all, the collected data was described clearly. A frame was determined for the data analysis regarding to the scope of the interviews. 3 people -who were expert at their study areas- selected the meaningful and logical data. Then, the experts categorized the data. Afterwards, these were explained and analyzed. While writing down the data, direct quotations were presented by using nicknames.

These answers were studied by descriptive analysis technic. After that, similar answers were made into group items and they were categorized in the same base. Following this, the answers were made into tables. The frequency numbers of each category in the tables were written next to it.

Table 1. The Distribution of the Mothers' Anxieties About Their Children's Future

\begin{tabular}{|c|c|}
\hline The Evaluation of the Mothers' Anxieties About Their Children’s Future & $\mathrm{n}$ \\
\hline Alienating from Turkish culture and become ashamed of his identity & 24 \\
\hline Having a cultural dilemma and finding our values nonsense & 22 \\
\hline Being unable to internalize what relationship is & 22 \\
\hline Not wanting to learn Turkish and forget his language & 21 \\
\hline Getting married to a non-Turkish person & 15 \\
\hline Admiring the foreign & 13 \\
\hline Hiding, not being able to learn, not living the religion and becoming ashamed of it & 12 \\
\hline Not caring to respect for the elder & 9 \\
\hline Access to the bad habits easily (drug abuse) & 9 \\
\hline Not wanting to come back Turkey & 7 \\
\hline Technology addiction & 7 \\
\hline Bullying at school or being exposed to bullying & 6 \\
\hline Having a boyfriend/ girlfriend at an early age & 6 \\
\hline Forgetting our food culture & 5 \\
\hline Problems in adapting while in Turkey & 4 \\
\hline Forgetting and not caring about the Turkish history & 3 \\
\hline Not being able to study in better colleges because of high expenses & 3 \\
\hline The disadvantages of the habit of acquiring everything easily & 1 \\
\hline Not being able to learn to become patient & 1 \\
\hline Brand obsession & 1 \\
\hline No intention to make a family and continue it & 1 \\
\hline Not knowing his environment because of not being able to look after the child & 1 \\
\hline
\end{tabular}

Not knowing his environment because of not being able to look after the child

As seen in Table 1, the mothers answered the question "What are your concerns for the future of your child?" in various ways. Among the answers, all the mothers defined their anxiety about 'alienating from Turkish culture and become ashamed of his identity'. This anxiety was followed by the situations such as 'having a cultural dilemma and finding our values nonsense', 'being unable to internalize what relationship is', 'not being want to learn Turkish and forget his language'.

15 mothers defined their children's 'getting married to a non-Turkish person', 12 mothers defined their children's 'becoming ashamed of the religion' as their anxieties. 9 mothers defined their children's 'access to the bad habits easily (drug abuse)' and 'not caring respect for the elder' as their anxieties. This was followed by 7 mothers' anxieties about 'not wanting to come back Turkey' and 'technology addiction'. The anxiety situations as 'bullying at school or being exposed to bullying', 'having a boyfriend/ girlfriend' and 'forgetting about the food culture' were in similar numbers. While 4 mothers defined her children's problems in 'adapting while in Turkey' as anxiety situations, 3 mothers defined their children's 'not being able to study in better colleges because of high expenses' as anxieties. Only 1 mother out of 24 mothers included in the study defined her child's 'brand obsession' and again 1 mother defined her child's having 'no intention to make a family and continue it' as an anxiety.

As seen in Table 2, for mothers in higher socioeconomic level, the most frequent cases that display anxiety situations were 'alienating from Turkish culture and become ashamed of his identity', 'having a cultural dilemma and finding our values nonsense', 'getting married to a non-Turkish person', 'unable to internalize what relationship with the relatives is' and 'access to the bad habits easily (drug abuse)'. These were followed by 'admiration to foreign' and 'not wanting to learn Turkish and forget his language'. While 4 of the mothers defined their children's 'not wanting to come back Turkey' as anxiety situations, and 4 of them also defined their children's 'problems in adapting while in Turkey' as anxiety situations. The frequencies of 'technology addiction' and 'hiding, not being able to learn, not living the religion and becoming ashamed of it' were 4 in number as well. Only 2 of the mothers defined their 
children's 'having a boyfriend/ girlfriend at an early age' as their anxieties.

Table 2. The Distribution of the Mothers' Anxieties about Their Children's Future According to Socio- Economic Levels

\begin{tabular}{|c|c|c|}
\hline $\begin{array}{l}\text { Socio- } \\
\text { Economic } \\
\text { Level }\end{array}$ & $\begin{array}{l}\text { The Evaluation of the Mothers' Anxieties About } \\
\text { Their Children's Future According to Socio- } \\
\text { Economic Level }\end{array}$ & $\mathrm{n}$ \\
\hline \multirow{16}{*}{ HIGHER } & Alienating from Turkish culture and become & 9 \\
\hline & $\begin{array}{l}\text { Having a cultural dilemma and finding our values } \\
\text { nonsense }\end{array}$ & 9 \\
\hline & Getting married to a non-Turkish person & 9 \\
\hline & $\begin{array}{c}\text { Being unable to internalize what relationship with } \\
\text { relatives is }\end{array}$ & 9 \\
\hline & Access to the bad habits easily (drug abuse) & 9 \\
\hline & Admiring the foreign & 6 \\
\hline & $\begin{array}{c}\text { Not wanting to learn Turkish and forgetting his } \\
\text { language }\end{array}$ & 6 \\
\hline & Not wanting to come back Turkey & 4 \\
\hline & Problems in adapting while in Turkey & 4 \\
\hline & Technology addiction & 4 \\
\hline & Bullying at school or being exposed to bullying & 4 \\
\hline & $\begin{array}{l}\text { Hiding, not being able to learn, not living the } \\
\text { religion and becoming ashamed of it }\end{array}$ & 4 \\
\hline & Not caring to respect for the elder & 3 \\
\hline & Forgetting our food culture & 3 \\
\hline & $\begin{array}{c}\text { Forgetting and not caring about the Turkish } \\
\text { history }\end{array}$ & 3 \\
\hline & Having a boyfriend/ girlfriend at an early age & 2 \\
\hline \multirow{17}{*}{ MIDDLE } & Becoming ashamed of his identity & 9 \\
\hline & $\begin{array}{l}\text { Not wanting to learn Turkish and forgetting his } \\
\text { language }\end{array}$ & 9 \\
\hline & $\begin{array}{l}\text { Having a cultural dilemma and finding our values } \\
\text { nonsense }\end{array}$ & 8 \\
\hline & $\begin{array}{c}\text { Being unable to internalize what relationship with } \\
\text { relatives is }\end{array}$ & 7 \\
\hline & Getting married to a non-Turkish person & 6 \\
\hline & $\begin{array}{l}\text { Hiding, not being able to learn, not living the } \\
\text { religion and becoming ashamed of it }\end{array}$ & 5 \\
\hline & Admiring the foreign & 4 \\
\hline & Having a boyfriend/girlfriend at an early age & 4 \\
\hline & Not wanting to come back Turkey & 3 \\
\hline & Technology addiction & 3 \\
\hline & Not caring to respect for the elder & 2 \\
\hline & Bullying at school or being exposed to bullying & 2 \\
\hline & Forgetting our food culture & 2 \\
\hline & $\begin{array}{l}\text { Not being able to study in better colleges because } \\
\text { of high expenses }\end{array}$ & 1 \\
\hline & $\begin{array}{c}\text { The disadvantages of the habit of acquiring } \\
\text { everything easily }\end{array}$ & 1 \\
\hline & Not being able to learn to become patient & 1 \\
\hline & No intention to make a family and continue it & 1 \\
\hline \multirow{10}{*}{ LOWER } & $\begin{array}{c}\text { Alienating from Turkish culture and become } \\
\text { ashamed of his identity }\end{array}$ & 6 \\
\hline & $\begin{array}{l}\text { Not wanting to learn Turkish and forgetting his } \\
\text { language }\end{array}$ & 6 \\
\hline & Being unable to internalize what relationship is & 6 \\
\hline & Having a cultural dilemma & 5 \\
\hline & Not caring to respect for the elder & 4 \\
\hline & Admiring the foreign & 3 \\
\hline & $\begin{array}{l}\text { Hiding, not being able to learn, not living the } \\
\text { religion and becoming ashamed of it }\end{array}$ & 3 \\
\hline & $\begin{array}{c}\text { Not being able to study in better colleges because } \\
\text { of high expenses }\end{array}$ & 2 \\
\hline & $\begin{array}{l}\text { Not knowing his environment because of not } \\
\text { being able to look after the child }\end{array}$ & 1 \\
\hline & Brand obsession & 1 \\
\hline
\end{tabular}

The answers by some of the mothers in the higher socio-economic level to the question were as such:

Arzu: "I am concerned about my child's forgetting his own culture, and drifting away from our culture, traditions and customs. I am worried that my child will be assimilated into the American culture and he/she will behave us disrespectfully as other American kids. The risk of his/ her getting married to the foreigners disturbs me. I am also worried about their being addicted to bad habits (heroin, gangs, use of gun etc.)"

Zehra: "I am concerned about my child's not being able to learn Turkish or speaking it in an accent and his/ her growing up away from our relatives. I am worried that in the future if we ever want to return permanently, she/he will not be able to adapt to Turkey. Being away from Turkish culture, not having Turkish friends and my child's getting married to a foreigner worries me.

Pınar: "I feel afraid that my child will be disturbed because of being Turkish and his family's being Turkish. He might choose a foreign partner, be bullied by their friends, and feel that he belongs to none of the two cultures, thus he might have psychological problems. I am highly anxious about the thought of my child's getting the ugly and wrong characteristics of this country and living according to them.

Ayşe: "I am highly anxious about my daughter's forgetting Turkish culture and Turkish language, then not being able to contact with the close relatives in Turkey; her being exposed to boy-girl relationships that start really early, somehow her getting addicted to alcohol and drugs because of other people's force or tricking, the psychological and physiological effect of too much technology and her distress and health problems.

As also seen in Table 2, the mothers in middle socioeconomic level, defined their children's 'alienating from Turkish culture and become ashamed of his identity' and 'not wanting to learn Turkish and forgetting his language, as primary anxieties. This was the same for the mothers in the higher socio-economic level. 8 mothers defined their children's 'having a cultural dilemma and finding our values nonsense' as anxiety situations. This anxiety was in the second place for the middle-economical level. The anxiety that 'being unable to internalize what relationship is' was defined by 7 mothers as anxiety situations. While 6 mothers defined 'getting married to a non-Turkish person, 5 mothers defined 'hiding, not being able to learn, not living the religion and becoming ashamed of it' as anxiety situations. In this group 4 mothers defined 'having a boyfriend/ girlfriend at an early age' as anxiety situations. For the mothers in the lower socio-economic level, the anxiety situations 'not being able to study in better colleges because of high expenses', 'not being able to learn to become patient', 'the disadvantages of the habit of acquiring everything easily' and 'no intention to make a family and continue it' were at the lower place.

The answers by some of the mothers in the middle socio-economic level to the question were as such:

Nilay: "I am worried about my child's effected by the American young culture, for instance my child thinks it is being clever to speak up to the adults. My child sees American culture and people superior while seeing our culture inferior. I am also afraid of my child's not wanting to learn Turkish in the future."

Arzu: "I am concerned about not being able to support my son for the college he wants to attend. As we don't have many relatives around, he is not able to learn these concepts and he usually finds it very crowded when we and our relatives come together. And this adds to my concerns. I am also concerned about him, because he has got everything so easily in the USA and he has no idea what hardship is. I fear that he will not be able to act mature. 
Lale: "I am anxious about my child as he feels himself more American than a Turkish citizen and he is staggering between two cultures. He is also alienated from Turkish culture. I am concerned about not having close relatives around him and his marrying someone who is either foreign or not Muslim.

Neşe "I fear that my daughter will have a boyfriend at an early age. I am also concerned about her potential problems about language, not being able to learn our culture, and not being able to understand our jokes as she is not familiar to our own culture. I am worried about the end of our generation. Marriages with foreigners and normalizing their values are the exact opposite to our culture.

When the mothers in the lower socio-economic level were analyzed, anxieties in the first place were 'alienating from Turkish culture and become ashamed of his identity', 'not wanting to learn Turkish and forgetting his language', and 'being unable to internalize what relationship with relatives is'. These anxieties were followed by the situation 'having a cultural dilemma'. 4 mothers defined 'not caring to respect for the elder' and 3 mothers defined 'hiding, not being able to learn, not living the religion and becoming ashamed of it' as their anxieties. For the mothers in the lower socio-economic level, 'not knowing his environment because of not being able to look after the child' and 'brand obsession' were anxieties in the lower place.

The answers by some of the mothers in the lower socioeconomic level to the question were as such:

Sema: "I am concerned about my child's being assimilated into American culture more than Turkish culture. Not seeing Turkey as her own country, not being able to speak Turkish as if it is not her own mother tongue, and her weak relationship with the relatives in Turkey concerns me a lot."

Banu: "I fear that he will not be able to speak Turkish fluently and drift away from our culture, and he will want to celebrate the religious festivals (like Christmas) of this culture. I am also worried that his relationship with the relatives will be weak and he will not have enough education about religion and finally he will become ashamed of his religion.

Pelin: "I am concerned about my child's not being respectful enough to the parents, my child's weakening the relationship with the relatives, having problems in finding a proper friend, the depressions between the cultural gaps, excessive brand obsession and looking up to the clothe styles here.

\section{Conclusion, Discussion and Suggestions}

In the study the anxieties of the mothers with children of adolescence age were researched. This study aimed to display the anxieties of the Turkish mothers with different socio-economic levels about their children's future who live in the city of Philadelphia, the USA. The mothers included in the study were chosen according to the principle of voluntariness.

It was a drawback and limitation not including the fathers but collecting data only from mothers. We might suggest including fathers as well for the upcoming potential researches.
Another drawback was the sample group was lower in number. The researcher chose the mothers in this area because the number of the Turkish families living in Philadelphia was high. 52 mothers were contacted, 21 mothers were not included in the study, as they did not have children in the adolescence age. In addition, 7 mothers rejected to participate in the research. Therefore, this study was conducted within a limited number of mothers (24 mothers). The sample group could be higher in number in the upcoming potential researches.

In the process of literary review, no similar research was found upon this topic with any directly, one to one or objective and result resemblance.

The leading anxiety situations for the mothers participating in the study were 'alienating from Turkish culture and becoming ashamed of his identity', 'having a cultural dilemma and finding our values nonsense', 'being unable to internalize what relationship is', 'not wanting to learn Turkish and forgetting his language', 'getting married to a non-Turkish person' and 'access to the bad habits easily (drug abuse)'. These were followed by such anxieties as 'hiding, not being able to learn, not living the religion and becoming ashamed of it' and 'not caring to respect for the elder'. This was, in fact, an expected result for the families living abroad. The Turkish nation is attached to its own culture, traditions and customs. Therefore, the Turkish people struggled more to conserve the values and transfer them to their children in a culture which was quite foreign to them. The life styles and value systems of the culture they were living in could sometimes be seen as more attractive. At the same time, the young people were studying at school all day. Therefore, it is possible to claim they could easily adapt to the cultural aspects of the culture they were living in without noticing. These concerns could be constituted as a result of not having institutions for religion, the relatives' living in Turkey and only contact with relative was only with the Turkish there.

The second generation Turkish children in the United States of America preferred English intensively in proportion to the time spent with the family and as they got older. As a consequence, the children were observed to feel themselves closer to the foreign culture as time passes. [13].

When the studies upon Turkish people living in Europe were analyzed similar results might be found.

In a project carried by Çil (2011) [14]; Turkish people living in European countries severely defined such problems as not having education in Turkish and Turkish culture, not being able to get religion education, not having an education programme for bilingual children. The people were interviewed about the providing of Turkish and Turkish culture education. 78\% of them defined this need as 'highly important' and 18,9\% of them defined this need as 'important'. It was seen that $73 \%$ of them found that it was 'highly important' to develop the religion services, and $22,1 \%$ of them defined that was 'important'.

When one analyzed the anxieties of the mothers, with different socio-economic levels, about their children's future, it was observed that although there were some common anxieties, these anxieties were different in levels of proportions. Baer's study supports that. In a research upon poor families conducted by Baer et al. (2012) [15] to 
analyze their anxiety disorders, it was found that the poorest mothers were higher in number who had a generalized anxiety disorder. In addition the poor mothers' anxieties were caused by more environmental deficiencies than psychiatric reasons.

When we analyzed the anxieties of the mothers about their children's future in different socio-economic levels, there were various outcomes. For all the mothers in higher, middle and lower socio-economic levels, their children's 'alienating from Turkish culture and become ashamed of his identity' was an anxiety that ranked in the first place. The reason for this can be explained as such: regardless of the socio-economic level, some cultural values could die out easily in a foreign country and foreign culture. In the adolescence period, a foreign culture might appear more attractive. The children in these ages might be more susceptible to this culture when they spend time with other children from that culture.

For the mothers in higher socio-economic level 'having a cultural dilemma and finding our values nonsense' was defined as an anxiety situation in a higher number. However, for the mothers in middle and lower socioeconomic levels, this anxiety ranked in the second place. This difference had some reasons. The families in the higher socio-economic level had more opportunities. They needed to participate more cultural activities outside the school with other foreign friends from that culture and follow the foreign cultural elements. In as much as, the young person might need to follow the values of his friend group in order not to be excluded from the group. This, therefore, brought the idea of accepting the values of the group, in other words, the culture. However, when the Turkish culture was more dominant at home, the young could stagger between the two cultures. There were similar findings to this research in the study of [16]. Arıkan and Doğan (2013) [16]). It was stated that parallel to the rise in the income of the family, the students' attitudes to the cultural heritage rose. The students with lower income level had less positive attitudes than those with higher income level.

For the mothers in the middle and lower socioeconomic levels, the anxiety that 'not wanting to learn Turkish and forgetting his language' was in the first place. However, this anxiety ranked in the lower places for the mothers in higher socio-economic levels. Within the mothers of middle socio-economic levels, 9 mothers defined 'not wanting to learn Turkish and forgetting his language' as anxiety situations, but for the mothers in the higher socio-economic level this number was 6 . It can be suggested that for the families in middle and lower socioeconomic levels, the thought of coming back to Turkey was much more because of the economic level they were living in. Thus, they had the anxiety about their children's forgetting Turkish more than the other mothers did. The results of [13] Ertem (2013) did not support this. The Turkish families, in the study of [13] Ertem (2013), thought that as long as they kept talking Turkish at home, the children would not forget Turkish. The family believed that, as long as the family provided their children with Turkish and Turkish culture, their children would not be assimilated by the American culture.

Another finding in the research was the anxiety for the child, who might fail to 'internalize what relationship with the relatives is'. This was defined in the first place by the mothers in higher and lower socio-economic levels, but for the mothers in middle socio-economic level, this anxiety ranked at the third place. This can be explained by the existence of busy mothers in higher and lower socioeconomic levels. They were not able to spend enough time with the relatives. The families in the lower socioeconomic levels spent their day only by working sometimes- in two different jobs in their struggle to live. On the other hand, the families in the higher socioeconomic levels intensively worked for big firms. They could neither come together with their relatives nor had a high number of relatives near them.

Although mothers in the upper socio-economic level experienced the anxiety 'access to the bad habits easily (drug abuse)' in higher numbers, mothers in middle and lower socio-economic levels did not mention such kind of anxiety. It is possible to think that the young people in the higher socio-economic level had more financial opportunities. As a result, these young people had more chances to become friends with their peers coming from the families in the same socio-economic level. Mothers felt that anxiety since drug abuse was highly common among teenagers and among -even- children compared to previous years. On should also consider that the access might be easier for people in some economic levels.

Even though more mothefs felt anxious about their children's marrying someone foreign, for the mothers in middle socio-economic level, this anxiety's frequency number was less. On the one hand, in the families with lower socio-economic level, no anxiety for that was seen. On the other hand, the families with higher socioeconomic level spent more time with American families and this situation raised the possibility of their children to get married one of the children of these families.

For mothers both in the higher and middle socioeconomic levels, it was in the same frequency numbers that the child's 'not wanting to come back to Turkey'. For the families in lower socio-economic levels, it was not defined as an anxiety situation. Also, 'having problems in adapting while in Turkey' was defined as an anxiety situation for the mothers in higher socio-economic levels. This was not defined as an anxiety situation for the mothers in middle and lower socio-economic levels. This result could be associated with the fact that families in the lower socio-economic level were overwhelmed by their struggle for life and they might be insisted upon staying there as a result of their low standards of living. At the same time, the families in the higher socio-economic level had better standards of living, and the young would not have these opportunities after they came back to Turkey. Therefore, they might not have an inclination to come back to Turkey.

For the mothers in the higher socio-economic level 'hiding, not being able to learn, not living the religion and becoming ashamed of it' was an anxiety ranked in the third place. However, for the mothers in the middle socioeconomic level it was in the fifth place. For the mothers in the lower socio-economic level that anxiety was in the fourth level, though.

In a study conducted by [1] Nuruan and collogues (2005) in Germany; people answered the question 'What are the reasons that makes you worried about your children's living in Germany?'. The highest proportions in the answers were that 'our children's not being able to 
learn our culture' (81.7\%) and 'our children's not being able to learn our religion' (77.2\%). These answers were followed by 'the dangers of drug abuse and alcohol' (65.1\%). While the proportion of the people who worried about 'their children's drifting away from the family' was $49.2 \%$, the anxiety of 'not being able to have a better education' was $40.4 \%$. The anxiety of 'being attacked by the foreign enemy groups' was lower in the proportion $39.9 \%$.

In this study there was another finding. For the mothers in the higher socio-economic level 'technology addiction' was in the third place for an anxiety situation. However, for the mothers in the middle socio-economic level, this anxiety was in the seventh place. Mothers in the lower socio-economic level did not define 'technology addiction' as an anxiety situation.

As seen from the study, the more the socio-economic level increased, the more anxious people felt about technology addiction. Especially, the access to different technological opportunities might rise according to the socio-economic levels of the individuals. This also appeared among the young living in the USA, the country of technological innovation and speed. Various problems might arouse while trying to use these technological opportunities in a controlled way.

'Not being able to study in better colleges because of high expenses' was defined as an anxiety situation for the mothers in middle and lower socio-economic levels. However, the mothers in higher socio-economic levels did not define it as an anxiety situation. This was an expected outcome. It could be suggested that the higher the targets were, the higher the possibility to create anxiety was. Generally, the families in the higher socio-economic level already had the opportunities to send their children to better colleges. Along with that, the families of upper socio-economic level canalized their children to sportive and artistic activities more. Therefore, the young students became successful and this helped them to study in better colleges with a scholarship.

The mothers defined their children's 'brand obsession' as an anxiety and 'not knowing his environment because of not being able to look after the child' as anxieties. It was in the lower ranking, though. Other mothers did not define these kinds of anxieties. It can be suggested that mothers in the lower socio-economic level couldn't afford expensive things with brands because of economic hardship and this would make them live this anxiety more. It can also be stated that these families worked in hard labor or they worked in different number of jobs. As a result, these conditions might lead to their not spending enough time with their children. They did not get to know their children's friends and environment. Then, they feel anxious about this.

For these findings these suggestions can be presented;

1. For the young people living in a foreign culture, the appropriate and sufficient education conditions can be provided to raise their mother tongue level. In this way, various courses can be opened and social activities can be organized.

2. The Ministry of National Education started 'The education program to teach Turkish language and Turkish culture for the Turkish children living abroad' during 2009- 2010 semesters. There can be studies to increase the activities of this programme. The problems in this programme can be solved.

3. In order to gather families and especially young people living abroad, the institutions and organizations can be established. These could be supported and organized by Turkey.

4. These institutions and organizations can contact with the administration and the teachers of the schools that our young students. They can also make family collaboration workshops, organize plans according to the needs of the mothers and share them with the families at the beginning of each semester.

5. Anxiety can turn into a behavioral style of an individual in time. It is possible to say that providing psychological help and mother (family) education support will be helpful.

6. There can be educations on developing mothers' communication skills.

7. It might be suggested to include fathers for the upcoming potential researches. Therefore, more inclusive data can be collected.

8. The sample group can be higher in number by including other areas where majority of Turkish families live.

\section{References}

[1] Nuruan,M.; Günes,,T.; BederŞen,R.; Günes,,S.; Kalaycı,S.A. \& Kaplan,M., Federal Almanya'da yaşayan Türklerin aile yapısı ve sorunları araştırması. Aile ve Sosyal Araştırmalar Genel Müdürlüğü, Ankara, 2005.

[2] Arslan,M., “Almanya'daki Türk işçi çocuklarının eğitim sorunları”, Sosyal bilimler enstitüsü dergisi, 2006, 21, (2), pp. 233-245.

[3] Yılmaz, M.Y., "İki dillilik olgusu ve Almanya'daki Türklerin iki dilli eğitim sorunu", Turkish studies - international periodical for the languages, literature and history of Turkish or Turkic, 2014, 9, 3, pp. 1641-1651.

[4] Portes, A. \& Schauffler, R., "Language and the Second Generation: Bilingualism Yesterday and Today”, International migration review, 1994, 28 (4), pp. 640-661.

[5] Fairclough, N. Language and power, Longman. London, (1989).

[6] Halberstadt, A. G.; Cassidy, J.; Stifter, C. A.; Parke, R. D. \& Fox, N. A., "Self-expressiveness within the family context: Psychometric support for a new measure”, Psychological assessment, 1995, 7, pp. 93-103.

[7] Spielberger, C. Cross-cultural anxiety, Distributed-solely by halsted press, New York, 1976.

[8] Öner, N. ve Le Compte, A. Durumluk-sürekli kaygı envanteri el kitabı, Boğaziçi Üniversitesi Yayınları, İstanbul, 1983.

[9] Özer, K., Kayg1, Sistem yayınc1lık, İstanbul, 2001.

[10] Köknel, O., Kaygıdan korkuya. Remzi kitabevi, İstanbul, 2013.

[11] Yıldırım,A.\& Şimşek,H., Sosyal bilimlerde nitel araştırma yöntemleri. $5^{\text {th }}$ Press. Seçkin yayıncılık, Ankara, 2005.

[12] Altunışık, R.; Coşkun, R;, Yıldırım, E. \& Bayraktaroğlu, S., Sosyal Bilimlerde Araştırma Yöntemleri, Sakarya Kitabevi, Adapazarı, 2001.

[13] Ertem,İ.S., "Yurt dışında yaşayan ikinci kuşak Türk çocuklarının Türkçeyi kullanım durumları ve dil-kültür ilişkisi”, Uşak üniversitesi sosyal bilimler dergisi, 2013, 6, (4), pp. 261-270.

[14] Çil,Ş.A.), Avrupa'da yaşayan Türkler. Yaz tatili döneminde Türkiye'ye gelen Türkler örneği (saha araştırması). T.C Başbakanlık Yurtdışı Türkler Ve Akraba Topluluklar Başkanlığı, Ankara, 2011.

[15] Baer,J.; Kim,M. \& Wilkenfeld, B.,’'Is it generalized anxiety disorder or poverty? An examination of poor mothers and their children”, Child adolesc soc work j, 2012, 2, pp. 345-355.

[16] Arıkan,İ. \& Doğan,Y., "İlköğretim 7. sınıf öğrencilerinin kültürel mirasla ilgili başarı düzeyleri ve tutumlarının bazı değişkenlerce incelenmesi (Adıyaman Örneği), Adıyaman üniversitesi sosyal bilimler enstitüsü dergisi, 2013, 5, pp. 29-68. 